\title{
Adsorption of metal ions on lignin
}

\author{
Xueyan Guo, Shuzhen Zhang*, Xiao-quan Shan \\ State Key Laboratory of Environmental Chemistry and Ecotoxicology, Research Center for Eco-Environmental Sciences, \\ Chinese Academy of Sciences, P.O. Box 2871, Beijing 100085, China \\ Received 1 December 2006; received in revised form 21 May 2007; accepted 22 May 2007 \\ Available online 26 May 2007
}

\begin{abstract}
This study investigated the adsorption of the heavy metal ions $\mathrm{Pb}(\mathrm{II}), \mathrm{Cu}(\mathrm{II}), \mathrm{Cd}(\mathrm{II}), \mathrm{Zn}(\mathrm{II})$, and $\mathrm{Ni}(\mathrm{II})$ on a lignin isolated from black liquor, a waste product of the paper industry. Lignin has affinity with metal ions in the following order: $\mathrm{Pb}$ (II) $>\mathrm{Cu}$ (II) $>\mathrm{Cd}$ (II) $>\mathrm{Zn}$ (II) $>\mathrm{Ni}$ (II). The adsorption kinetic data can be described well with a pseudosecond-order model and the equilibrium data can be fitted well to the Langmuir isotherm. Metal ion adsorption was strongly dependent on $\mathrm{pH}$ and ionic strength. Surface complexation modelling was performed to elucidate the adsorption mechanism involved. This shows that lignin surfaces contain two main types of acid sites attributed to carboxylic- and phenolic-type surface groups and the phenolic sites have a higher affinity for metal ions than the carboxylic sites.
\end{abstract}

(C) 2007 Elsevier B.V. All rights reserved.

Keywords: Lignin; Surface complexation model; Heavy metal ions; Adsorption

\section{Introduction}

Water pollution is a serious problem and heavy metals are common pollutants in water that threaten human health and environmental quality. Methods of minimizing heavy metal concentrations in surface waters and wastewaters are therefore crucial for environmental protection. The main techniques that have been used to remove heavy metals from water include chemical precipitation, membrane filtration, ion exchange, and adsorption on activated carbon [1-6]. However, these methods have limitations such as high operational costs in the case of adsorption by activated carbon and difficulties meeting strict regulatory requirements in the case of chemical precipitation. Intensive studies have therefore been carried out to develop more effective and inexpensive metal adsorbents. Candidate materials include industrial or agricultural waste products such as waste slurry $[7,8]$, fly ash $[9,10]$, lignite $[11,12]$ pine bark [13], peat [14,15], and lignin [16-25]. Babel and Kurniawan [26] and Bailey et al. [27] have reviewed the application of low-cost adsorbents for heavy metal removal from contaminated waters.

Lignin is a natural polymer that is present in large quantities in the cell walls of terrestrial plants and is the main binding agent

\footnotetext{
* Corresponding author. Tel.: +86 1062849683 ; fax: +86 1062923563.

E-mail address: szzhang @mail.rcees.ac.cn (S. Zhang).
}

for fibrous plant components, typically comprising from 16 to $33 \%$ of plant biomass. More than $50 \times 10^{4}$ metric/tonnes/year of lignin are produced worldwide by pulping [28,29]. About $90-95 \%$ of the reactive lignin biopolymer is solubilized to oligomers that contribute to the pollution load. Lignin disposal is therefore subject to significant environmental constraints.

Lignin is a natural amorphous cross-linked resin that has an aromatic three-dimensional polymer structure containing a number of functional groups such as phenolic, hydroxyl, carboxyl, benzyl alcohol, methoxyl, and aldehyde groups [30], making it potentially useful as an adsorbent material for removal of heavy metals from water. Suhas et al. [31] have reviewed the literature on lignin as a biosorbent. Srivastava et al. [16] obtained remarkably high uptake of $\mathrm{Pb}$ (II) and $\mathrm{Zn}$ (II), up to 1587 and $73 \mathrm{mg} / \mathrm{g}$ for $\mathrm{Pb}$ (II) and $\mathrm{Zn}$ (II), respectively, by using lignin extracted from black liquor. Demirbas [24] reported a maximum adsorption capacity of $8.2-9.0 \mathrm{mg} / \mathrm{g}$ for $\mathrm{Pb}$ (II) and $6.7-7.5 \mathrm{mg} / \mathrm{g}$ for $\mathrm{Cd}(\mathrm{II})$ on lignin from beech and poplar wood modified by alkaline glycerol delignification. From the above data and the review by Suhas et al. [31] we find that there are significant differences in the metal sorption capacities of different types of lignin. Moreover, the related mechanisms of metal sorption by lignin are still subject to debate. Some studies have found that ion-exchange mechanisms may be responsible for the sorption of metal ions on lignin [17,21-23]. Srivastava et al. [16] and Mohan et al. [20] suggested that no single mechanism could explain the pro- 
cess of metal removal by lignin. Several processes including ion exchange, surface adsorption, and complexation, have been suggested to explain the mechanisms involved. Detailed studies are therefore required to achieve a quantitative and mechanistic understanding of the sorption of metal ions by lignin.

The aim of the present study was to obtain a quantitative and mechanistic description of the adsorption of the metals ions $\mathrm{Pb}(\mathrm{II}), \mathrm{Cu}(\mathrm{II}), \mathrm{Cd}(\mathrm{II}), \mathrm{Zn}(\mathrm{II})$, and $\mathrm{Ni}(\mathrm{II})$ on lignin based on surface characterization and metal ion adsorption. The surface physico-chemical characteristics of lignin such as surface site densities, acidity constants, and metal binding constants, were investigated by potentiometric titrations and metal ion adsorption experiments. Surface complexation modelling was performed to elucidate the adsorption mechanisms involved.

\section{Materials and methods}

\subsection{Adsorbent characteristics}

Lignin was obtained from a paper mill in Yunnan Province, south China as follows. The black liquor, a recycled by-product of the pulping of wood, was acidified to $\mathrm{pH} \mathrm{2-3}$ with sulfur dioxide. The liquid-sediment suspension was transferred to a lignin reactor in which solids and acid liquor were separated at $60-80{ }^{\circ} \mathrm{C}$. The solids containing $80 \pm 2 \%$ lignin were dried and termed lignin. Prior to the experiments the lignin was washed with deionized water $(20 \mathrm{~g} / \mathrm{L})$ shaken on an end-over-end shaker for $12 \mathrm{~h}$ and filtered. This procedure was repeated three times, and the solid obtained was oven-dried at $45^{\circ} \mathrm{C}$ for one day and ground to pass a $0.25-\mathrm{mm}$ standard sieve. Lignin prepared in this way was then ready for use in the following experiments.

Total C, H, N, and S contents of the lignin were determined by dry combustion in an autoanalyzer (Vario EL, Elementar Analysensyteme, Hanau, Germany). The $\mathrm{pH}$ value of a lignin suspension was measured using a solid-to-water ratio of 1:1 (w/v). Cation exchange capacity (CEC) was determined by the method of Rhodes [32]. Specific surface area and pore diameter were measured using a Micromeritics Flowsorb II surface area analyzer (ASAP 2000, Micromeritics Company, Norcross, GA), and by applying the BET equation to the sorption of $\mathrm{N}_{2}$ at a relative partial pressure of 0.3 at $77 \mathrm{~K}$. The Fourier-transformed infrared spectra (FT-IR) were recorded with pellets obtained by pressing a mixture of $1 \mathrm{mg}$ of sample and $100 \mathrm{mg}$ of $\mathrm{KBr}$ under reduced pressure using a Perkin-Elmer GX2000 Fourier transform infrared spectrophotometer.

\subsection{Adsorption kinetics}

The kinetic experiments were performed in 500-ml batch reactors at $20^{\circ} \mathrm{C}$. One gram of lignin was firstly mixed thoroughly with $400 \mathrm{ml}$ of a $0.01 \mathrm{M} \mathrm{NaNO}_{3}$ electrolyte solution in a flask. Prior to the introduction of the metal ions, the suspension was magnetically and vigorously stirred for $2 \mathrm{~h}$ to hydrate the lignin. The initial concentration of the metal ions $\mathrm{Pb}$ (II), $\mathrm{Cu}$ (II), $\mathrm{Cd}(\mathrm{II}), \mathrm{Zn}(\mathrm{II})$, and $\mathrm{Ni}(\mathrm{II})$ was $0.8 \mathrm{mM}$. After the introduction of the metal ions individually the samples were magnetically stirred, collected at different time intervals, and filtered through a $0.45-\mu \mathrm{m}$ cellulose acetate membrane. The metal concentrations in the filtrate were determined by inductively coupled plasma optical emission spectrometry (ICP-OES, Optima 2000 DV, Perkin Elmer, Wellesley, MA). The quantity of metal adsorbed was deduced from the mass balance between the initial concentration and the concentration in solution at a given time.

\subsection{Adsorption isotherms}

The adsorption isotherms were determined by a batch technique in a background electrolyte of $0.01 \mathrm{M} \mathrm{NaNO}_{3}$ at $20^{\circ} \mathrm{C}$. A $20-\mathrm{ml}$ aliquot of $2.5 \mathrm{~g} / \mathrm{L}$ lignin suspension was transferred to a $40 \mathrm{ml}$ polyethylene centrifuge tube. The initial concentrations of each metal ranged from 0.2 to $2.5 \mathrm{mM}$. The $\mathrm{pH}$ of the system was maintained at 5.5. After the samples were shaken end-overend for $24 \mathrm{~h}$ the suspensions were centrifuged at $7200 \times g$ for $15 \mathrm{~min}$, filtered through a $0.45-\mu \mathrm{m}$ cellulose nitrate membrane, acidified, and analyzed for metal ion concentrations.

\subsection{Effect of $p H$ on the adsorption}

One gram of lignin was introduced into a reaction vessel with $400 \mathrm{ml}$ background electrolyte inside and hydrated for $2 \mathrm{~h}$. The suspension was then spiked with metal stock solution to achieve a starting concentration of $0.2 \mathrm{mM}$ for each metal ion. The suspension was stirred and titrated to higher $\mathrm{pH}$ by stepwise addition of dilute $\mathrm{HNO}_{3}$ or $\mathrm{NaOH}$. After each $\mathrm{pH}$ increment was reached a $20-\mathrm{ml}$ aliquot was transferred from the reaction vessel to a 40-ml centrifuge tube and shaken at $25 \mathrm{rpm}$ on an endover-end shaker for $24 \mathrm{~h}$. Afterwards, the final $\mathrm{pH}$ was measured and the suspensions were centrifuged, filtered, acidified, and analyzed for metal ion concentrations. To examine the effect of ionic strength, adsorption of metal ions on lignin was performed in background electrolytes of 0.01 and $0.1 \mathrm{M} \mathrm{NaNO}_{3}$.

\subsection{Potentiometric titrations}

An automatic titration system (Microprocessor 682, Metrohm) was employed at a constant temperature of $25.0 \pm 0.2^{\circ} \mathrm{C}$. For each titration a given volume of the stock suspension in a reactor (100-ml conical flask) was diluted using 1.0 $\mathrm{M} \mathrm{NaNO}_{3}$ solution and deionized water to a particle concentration of $2 \mathrm{~g} / \mathrm{L}$. Three final ionic strengths in the sample suspensions supported by the background electrolyte $\left(\mathrm{NaNO}_{3}\right)$ were $0.005,0.01$, and $0.1 \mathrm{M}$, respectively. The reactor, equipped with a combined glass electrode, was agitated using a magnetic stirrer and purged with pure $\mathrm{N}_{2}$ during the whole titration procedure. Nitrogen gas was prepurified by passing through wash bottles containing $\mathrm{NaOH}(0.1 \mathrm{M})$ and $\mathrm{HCl}(0.1 \mathrm{M})$, and then saturated with distilled water. A back-titration procedure was carried out by which the suspension was first acidified to an approximate $\mathrm{pH} 3$ and then back-titrated with a standardized $0.0979 \mathrm{M} \mathrm{NaOH}$ solution at a rate of $0.01 \mathrm{ml} / \mathrm{min}$ until the $\mathrm{pH}$ exceeded 8.0. Stable $\mathrm{pH}$ values were recorded when the drift of the potential of the glass electrode cell was less than $10 \mu \mathrm{V} / \mathrm{s}$. Blank titrations were also performed under the same experimental conditions. 


\subsection{Applied models}

\subsubsection{Adsorption models}

A pseudosecond-order kinetic model $[33,34]$ was used to fit the adsorption kinetic data using the equation

$\frac{t}{q_{t}}=\frac{1}{k q_{\mathrm{e}}^{2}}+\frac{t}{q_{\mathrm{e}}}$

where $k$ is the rate constant for the pseudosecond-order model and $q_{\mathrm{e}}$ and $q_{t}$ are the amounts of solute adsorbed per unit adsorbent at equilibrium and at time $t$, respectively. Herein, the initial adsorption rate $\left(v_{0}\right)$ is calculated as $v_{0}=k q_{\mathrm{e}}^{2}$.

\subsubsection{Nonelectrostatic surface complexation model}

A nonelectrostatic surface complexation model was used to describe the potentiometric titration and metal ion adsorption data. Proton dissociation from ligands on lignin surfaces can be described by the following reaction

$\mathrm{S}_{i} \mathrm{OH}=\mathrm{S}_{i} \mathrm{O}^{-}+\mathrm{H}^{+} \quad K_{\mathrm{ai}}$

The concentration of proton bonding surface sites and the acidity constants can be quantified with the corresponding mass action equation

$K_{\mathrm{ai}}=\frac{\left[\mathrm{S}_{i} \mathrm{O}^{-}\right]\left[\mathrm{H}^{+}\right]}{\left[\mathrm{S}_{i} \mathrm{OH}\right]}$

The complexation of a metal ion with lignin can be described by the following equilibrium reactions

$\mathrm{S}_{i} \mathrm{OH}+\mathrm{M}^{2+}=\mathrm{S}_{i} \mathrm{OM}^{+}+\mathrm{H}^{+} \quad K_{\mathrm{Mi}}$

The concentrations of surface sites, $\log K_{\mathrm{ai}}$ values for the proton dissociation reactions, and $\log K_{M i}$ values for the metal ion sorption reactions were calculated using the computer program FITEQL 4.0 [35]. The total concentration of reacting protons (TOTH) was necessary to calculate the surface site concentrations and acidity constants. In this study the Gran plot method [36] was adopted to determine the specific volume of titrant added at the equivalent point $\left(V_{\mathrm{e}}\right)$, and to derive the total concentration of reacting protons. The total concentration of reacting $\mathrm{H}^{+}$at each back-titration point, TOTH was calculated using the equation

TOTH $=\frac{-\left(V_{\mathrm{b}}-V_{\mathrm{e}_{1}}\right) \times C_{\mathrm{b}}}{V_{0}+V_{\mathrm{at}}+V_{\mathrm{b}}} \quad(\mathrm{mol} / \mathrm{L})$

where $C_{\mathrm{b}}$ is the concentration of $\mathrm{NaOH} ; V_{0}$ is the initial volume of lignin suspension; $V_{\text {at }}$ is the total volume of $\mathrm{HNO}_{3}$ added in the acid titration; $V_{\mathrm{b}}$ is the added $\mathrm{NaOH}$ volume recorded by a recording instrument during the titration procedure; $V_{\mathrm{e}_{1}}$, obtained from the results of linear regression analysis of the Gran plots, can be considered as the zero point of titration (ZPT).

The optimization procedure of FITEQL 4.0 involves the iterative application of a linear approximation of the chemical equilibrium equation and a nonlinear least-squares fit. An overall variance, weighted sum of squares divided by the degree of freedom (WSOS/DF), was calculated between the model fit and experimental data, thus providing a quantitative assessment of goodness of fit. For each data set, the surface sites and stability constants for each reaction were adjusted until a best-fit curve was obtained. Because of neglect of the electrostatic effects, the results were conditional on ionic strength and the stability constants $\log K_{\text {ai }}$ determined represent apparent constants, not intrinsic constants.

\subsection{Quality assurance}

Blanks were run in parallel in all the experiments. All the experiments were carried out in triplicate and the average values are reported. Quality assurance for metal analysis was carried out by the determination of the metal ion concentrations in water standard reference material (GBW 080080 purchased from Shanghai institute of measurement and testing technology, Shanghai, China). Good agreement was achieved between the data obtained and the certified values with the differences of less than $10 \%$.

\section{Results and discussion}

\subsection{Characterization of the lignin}

The elemental analysis shows that the lignin had the following percentage composition (\%): C, 60.8; H, 5.8; N, 1.3; S, 2.1; ash, 5.5; K, 0.24; Ca, 0.06; Na, 1.4; Mg, 0.01; Fe, 0.007; and Al, 0.03 . The $\mathrm{pH}$-value of the lignin suspension was 5.5 at a solidto-water ratio of $1: 1(\mathrm{w} / \mathrm{v})$, and the cation exchange capacity was $23.9 \mathrm{cmol} / \mathrm{kg}$. The average pore diameter was $147.6 \AA$ and the specific surface area of lignin was $21.7 \mathrm{~m}^{2} / \mathrm{g}$ as measured by the $\mathrm{N}_{2}$-BET method. The surface area was not as high as we expected $[16,20,24]$, probably due to the BET measurement method we used which has been demonstrated not to quantitively detect the inner surface area of some sorbents, resulting in lower specific surface area values [37]. The difference in physical and chemical properties of lignin from different origins and the extraction or isolation technology used may also have contributed to the lower specific surface areas to some extent.

The FT-IR spectrum of the lignin is shown in Fig. 1. The broad band at $3412 \mathrm{~cm}^{-1}$ was dominated by the stretching vibrations of aromatic and aliphatic $\mathrm{OH}$ groups. The peaks at 2925 and $2849 \mathrm{~cm}^{-1}$ predominantly arose from $\mathrm{C}-\mathrm{H}$ stretching in methyl

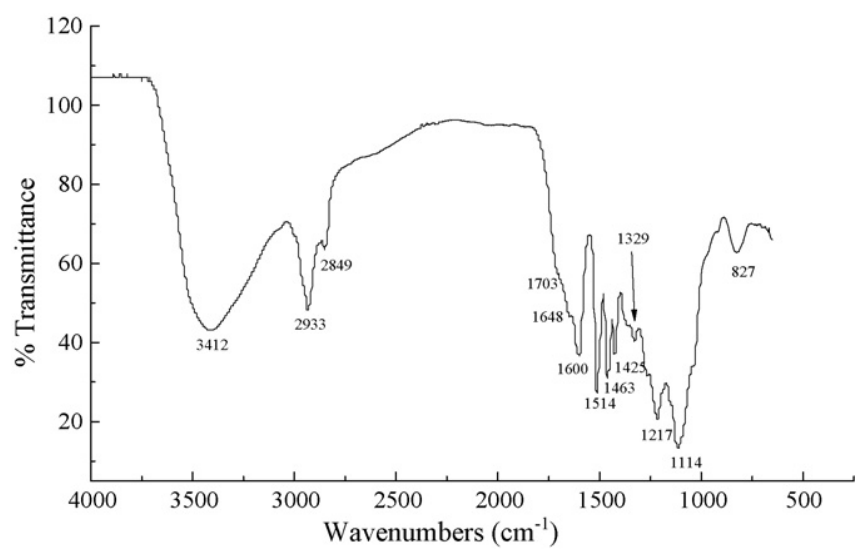

Fig. 1. FTIR spectra of lignin. 


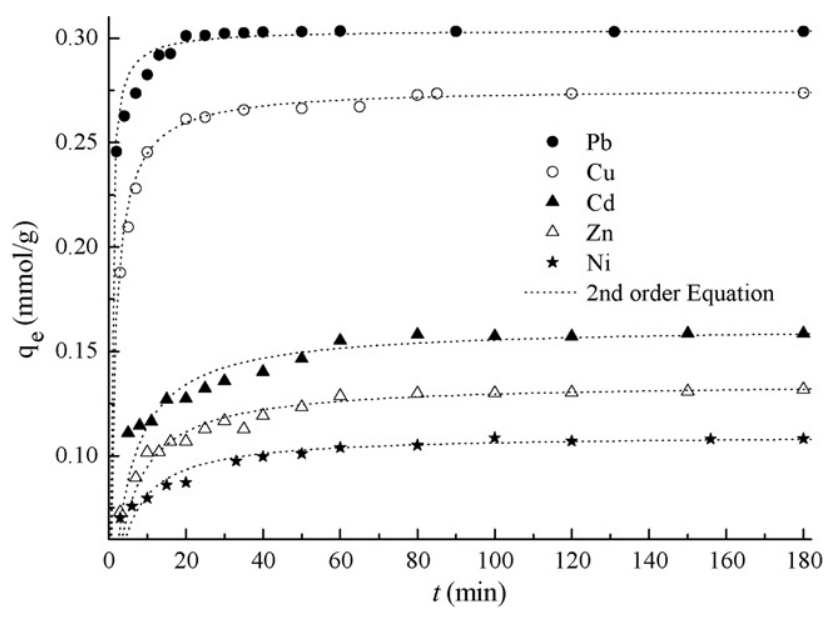

Fig. 2. Adsorption kinetics of metal ions on lignin with an initial metal concentration of $0.8 \mathrm{mM}$. Dotted lines represent the modeled results using the pseudosecond-order equation.

and methylene groups of side chains and aromatic methoxyl groups. Two shoulders at about 1703 and $1648 \mathrm{~cm}^{-1}$ originated from conjugated carboxyl and carbonyl stretching. Three strong peaks at 1600,1514 , and $1425 \mathrm{~cm}^{-1}$ could be assigned to typical aromatic skeletal vibrations. Absorption at $1463 \mathrm{~cm}^{-1}$ indicates aromatic methyl group vibrations. The peaks at 1329 and $1217 \mathrm{~cm}^{-1}$ depict syringyl ring $\mathrm{C}-\mathrm{O}$ stretching. The peaks at 1114 and $827 \mathrm{~cm}^{-1}$ further indicate the presence of syringyl units $[38,39]$. The signal assigned to carboxyl groups showed low intensity, but high intensities were observed at 1217 and $1514 \mathrm{~cm}^{-1}$, indicating that phenolic units were more abundant than carboxyl groups in the lignin [40].

\subsection{Metal adsorption characteristics}

\subsubsection{Adsorption kinetics}

Results of kinetic experiments are shown in Fig. 2. The five metal ions $\mathrm{Pb}$ (II), $\mathrm{Cu}$ (II), $\mathrm{Cd}(\mathrm{II}), \mathrm{Zn}(\mathrm{II})$, and $\mathrm{Ni}(\mathrm{II})$ had very similar kinetic adsorption. The adsorption equilibrium was reached with a minimum solid-solution contact time of approximately $20 \mathrm{~min}$. To evaluate the differences in the adsorption kinetic rates, the pseudofirst-order model, pseudosecond-order kinetic model and intraparticle diffusion model were tested for fit to the results. The rate law for a pseudosecond-order kinetic model best described the experimental data (Fig. 2) with the correlation coefficients $\left(r^{2}\right)$ of being over 0.9997. Successful fitting of the data with the second-order kinetic model suggests that chemisorption was the rate-controlling step [33,34]. Kinetic constants, including $v_{0}, k$, and $q_{\mathrm{e}}$ were calculated from the slopes and intercepts of the plots and are presented in Table 1. The initial adsorption rate $\left(v_{0}\right)$ values were in the following sequence: $\mathrm{Pb}(\mathrm{II})>\mathrm{Cu}(\mathrm{II})>\mathrm{Cd}(\mathrm{II}) \approx \mathrm{Zn}(\mathrm{II}) \approx \mathrm{Ni}(\mathrm{II})$. Furthermore, the very fast sorption kinetics observed with lignin represent an advantageous aspect when water treatment systems are intended and might be suitable for a continuous-flow treatment system.

\subsubsection{Adsorption isotherms}

Equilibrium sorption studies were performed to provide the maximum metal adsorption capacities of the lignin. The
Table 1

Pseudosecond-order kinetic parameters for the adsorption of metal ions on lignin

\begin{tabular}{lllll}
\hline Metal & $v_{0}(\mathrm{mmol} / \mathrm{g} / \mathrm{min})$ & $k(\mathrm{~g} / \mathrm{mmol} / \mathrm{min})$ & $q_{\mathrm{e}}(\mathrm{mmol} / \mathrm{g})$ & S.E. $^{\mathrm{a}}\left(\times 10^{3}\right)$ \\
\hline $\mathrm{Pb}(\mathrm{II})$ & 0.783 & 8.475 & 0.304 & 6.595 \\
$\mathrm{Cu}(\mathrm{II})$ & 0.218 & 2.872 & 0.276 & 4.258 \\
$\mathrm{Cd}(\mathrm{II})$ & 0.039 & 1.476 & 0.162 & 7.227 \\
$\mathrm{Zn}$ (II) & 0.032 & 1.765 & 0.135 & 5.595 \\
$\mathrm{Ni}$ (II) & 0.031 & 2.555 & 0.110 & 5.990
\end{tabular}

a S.E., $\left[\sum\left(q-q^{*}\right)^{2} /(n-2)\right]^{1 / 2}$, standard error; $q$ and $q^{*}(\mathrm{mmol} / \mathrm{g})$ represent the measured amount of the metal adsorbed and the predicted amount of the metal adsorbed by models, respectively; $n$, the number of experimental points.

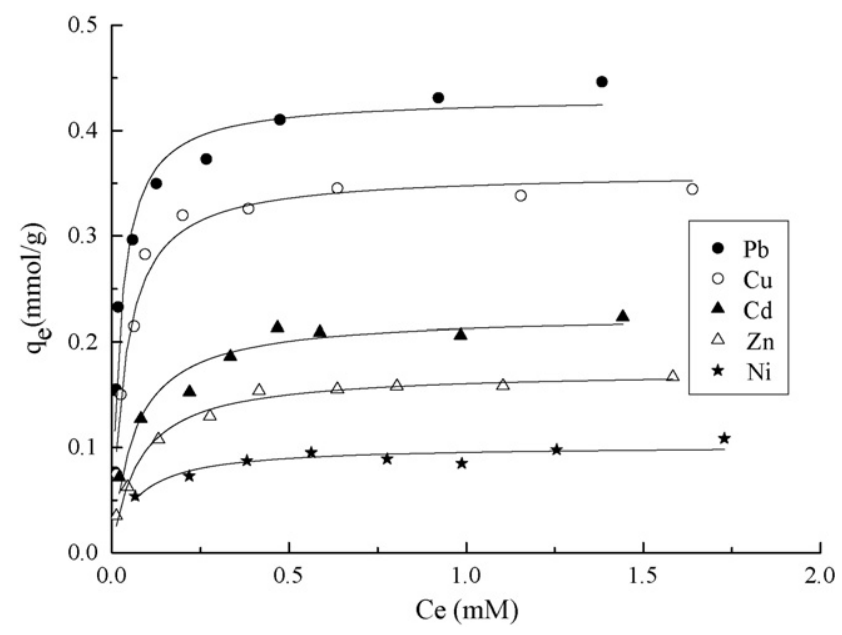

Fig. 3. Adsorption isotherms of metal ions on lignin. Solid line denotes the adsorption isotherm predicted using the Langmuir model.

adsorption isotherms of metals on lignin are shown in Fig. 3. The Langmuir equation was used to describe the adsorption isotherms as shown in Fig. 3, which fit the adsorption data better than the Freundlich equation. The values of $q_{\mathrm{m}}$ and $b$ obtained from the Langmuir equation fitting are listed in Table 2. The significant correlation coefficients $\left(r^{2}\right)$ obtained ranged from 0.8500 to 0.9884 . Similar to the adsorption kinetics, the maximum equilibrium adsorption capacity $\left(q_{\mathrm{m}}\right)$ was obtained for $\mathrm{Pb}$ (II) $(0.432 \mathrm{mmol} / \mathrm{g})$, which decreased to $0.360 \mathrm{mmol} / \mathrm{g}$ for $\mathrm{Cu}(\mathrm{II}), 0.226 \mathrm{mmol} / \mathrm{g}$ for $\mathrm{Cd}(\mathrm{II}), 0.172 \mathrm{mmol} / \mathrm{g}$ for $\mathrm{Zn}(\mathrm{II})$, and $0.102 \mathrm{mmol} / \mathrm{g}$ for $\mathrm{Ni}(\mathrm{II})$. The lignin in the present study showed higher adsorption capacities for the metal ions compared with the adsorption capacities of other lignin adsorbents published in the review paper [31] with the exception of the exceptionally high adsorption capacities reported by Srivastava et al. and Mohan et al. [16,20].

Table 2

Langmuir parameters for metal ion adsorption on lignin

\begin{tabular}{llll}
\hline Metal ion & $q_{\mathrm{m}}(\mathrm{mmol} / \mathrm{g})$ & $b(\mathrm{~L} / \mathrm{mmol})$ & $r^{2}$ \\
\hline $\mathrm{Pb}(\mathrm{II})$ & 0.432 & 43.11 & 0.9613 \\
$\mathrm{Cu}(\mathrm{II})$ & 0.360 & 27.38 & 0.9786 \\
$\mathrm{Cd}(\mathrm{II})$ & 0.226 & 15.97 & 0.9431 \\
$\mathrm{Zn}(\mathrm{II})$ & 0.172 & 13.38 & 0.9884 \\
$\mathrm{Ni}(\mathrm{II})$ & 0.102 & 14.74 & 0.8500 \\
\hline
\end{tabular}




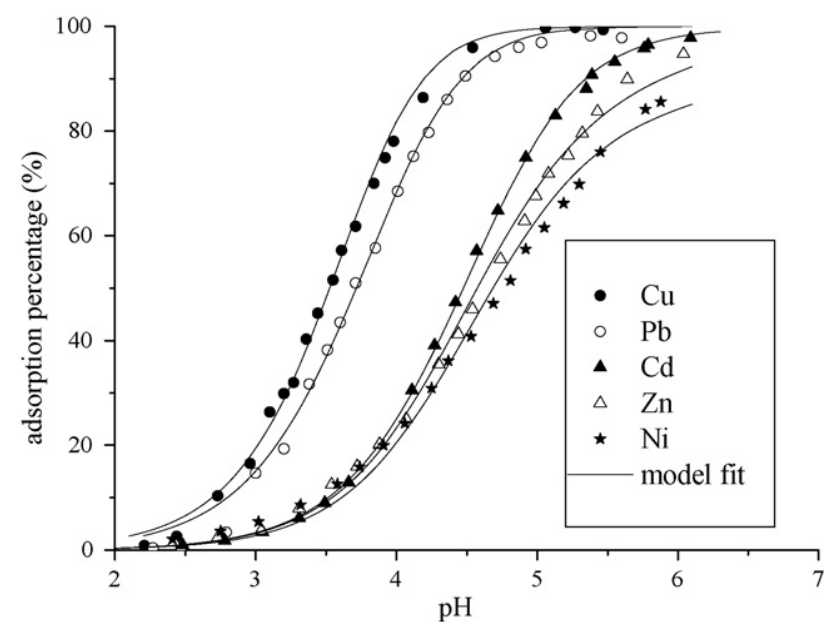

Fig. 4. Effect of pH on metal ion adsorption on lignin. The solid lines are predicted results using the parameters given in Tables 3 and 4 .

\subsubsection{Effects of $p H$}

Fig. 4 shows the percentage of metal ion adsorption for $\mathrm{Cu}(\mathrm{II}), \mathrm{Pb}(\mathrm{II}), \mathrm{Cd}(\mathrm{II}), \mathrm{Zn}(\mathrm{II})$, and $\mathrm{Ni}(\mathrm{II})$ on lignin as a function of $\mathrm{pH}$. Results indicate that metal adsorption was strongly $\mathrm{pH}$-dependent and increased with increasing $\mathrm{pH}$. Metal ion adsorption increased in a narrow $\mathrm{pH}$ range ( $2-3 \mathrm{pH}$ units), which is often called $\mathrm{pH}$ sorption edge. By increasing the $\mathrm{pH}$, the sorption edges were reached for $\mathrm{Pb}(\mathrm{II}), \mathrm{Cu}(\mathrm{II}), \mathrm{Cd}(\mathrm{II}), \mathrm{Zn}$ (II), and $\mathrm{Ni}(\mathrm{II})$ in this sequence. At $\mathrm{pH} 4$ over $81 \%$ of $\mathrm{Pb}$ (II) and $65 \%$ of $\mathrm{Cu}(\mathrm{II})$ were adsorbed, while less than $27 \%$ of $\mathrm{Cd}(\mathrm{II}), \mathrm{Zn}(\mathrm{II})$, and $\mathrm{Ni}(\mathrm{II})$ were adsorbed. When the $\mathrm{pH}$ was higher than 6 more than $85 \%$ of the metal ions were adsorbed on the surface efficiently. At higher $\mathrm{pH}$ precipitation may also have occurred. Crist et al. observed that metal ion sorption was accompanied by stoichiometric release of protons and existing metals, and concluded that ion exchange mechanisms were responsible for the removal of metals by lignin [21-23]. In order to see if a similar process was occurring in the present study, release of the cations $\mathrm{Na}^{+}, \mathrm{Mg}^{2+}$, and $\mathrm{Ca}^{2+}$ was recorded while the metal ion was adsorbed, by taking $\mathrm{Cu}$ as an example. Compared to the amount of $\mathrm{Na}^{+}$released, the release of $\mathrm{Mg}^{2+}$ and $\mathrm{Ca}^{2+}$ was negligible. When the $\mathrm{pH}$ value was increased from 2.5 to 4.5 , the molar ratios of $\mathrm{Na}^{+}$released to $\mathrm{Cu}(\mathrm{II})$ adsorbed were found between 1.28 and 1.39 , but when the $\mathrm{pH}$ value reached 4.8 , the ratio decreased to 0.66 . The amount of $\mathrm{Cu}(\mathrm{II})$ adsorbed was more than the equivalent cations released, indicating that there may some other mechanisms work in addition to ion exchange.

\subsubsection{Effects of ionic strength}

Effects of ionic strength showed a significant effect on metal ion adsorption on the lignin. Because of the similarity among the plots for different metals, only the effect of ionic strength on $\mathrm{Cu}$ adsorption is given in Fig. 5 as an example. Increasing the ionic strength from 0.01 to 0.1 led to a significant decrease in $\mathrm{Cu}(\mathrm{II})$ adsorption. The effect of ionic strength shows more effects on $\mathrm{Cd}(\mathrm{II}), \mathrm{Zn}$ (II), and $\mathrm{Ni}$ (II) than $\mathrm{Pb}$ (II) and $\mathrm{Cu}$ (II). The curves shifted to a higher $\mathrm{pH}$ by about $0.3-0.6 \mathrm{pH}$ units when the concentration of the background electrolyte of $\mathrm{NaNO}_{3}$ increased

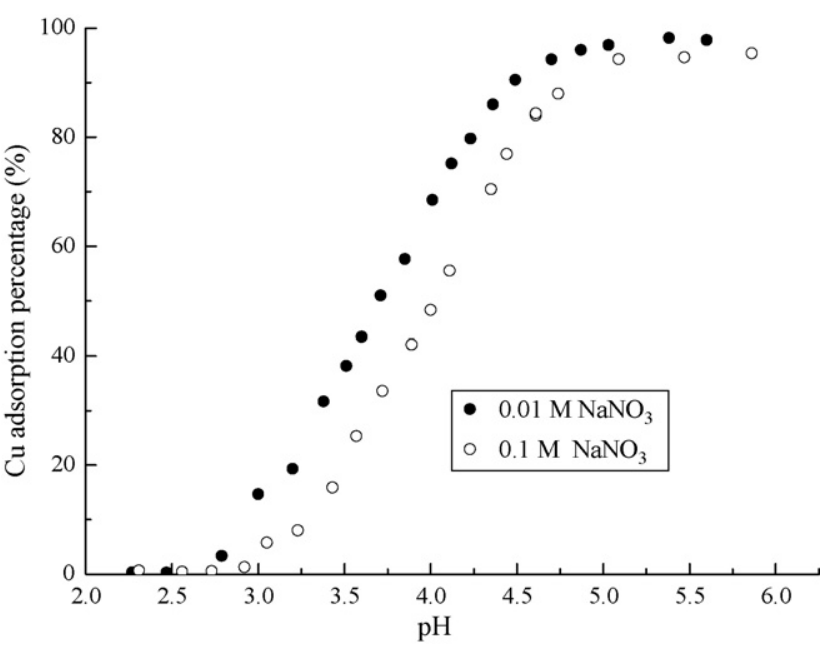

Fig. 5. Effect of ionic strength on $\mathrm{Cu}$ (II) adsorption on lignin as a function of $\mathrm{pH}$.

from 0.01 to $0.1 \mathrm{M}$ for the five metal ions. The effect of ionic strength on metal adsorption may be explained by the formation of outer-sphere complexes since $\mathrm{Na}^{+}$in the background electrolyte could compete with the metal ions adsorbed on the outer-sphere sorption sites and reduced the adsorption, whereas $\mathrm{Na}^{+}$would not have competed for the inner-sphere sites.

\subsection{Surface site concentrations and surface acidity}

Acid-base titration curves can provide important information about the concentration and acidity of surface functional groups. Potentiometric titrations of lignin suspensions at three different concentrations of background electrolyte were therefore performed. In the data treatment the Gran plot was adopted to determine the specific volume of titrant added at the equivalent point $\left(V_{\mathrm{e}}\right)$ and to derive the total concentration of reacting protons at each back-titration point. Fig. 6 illustrates the Gran plots for the back-titration data on lignin suspensions under three ionic strengths. The hydroxide ions added to the lignin suspensions were consumed by the following steps reflected in the plots: neutralization of excess $\mathrm{H}^{+}$in the suspension (before $V_{\mathrm{e}_{1}}$ ), reactions with the various acceptors on the lignin surfaces (between $V_{\mathrm{e}_{1}}$ and $V_{\mathrm{e}_{2}}$ ), and adjustment of the system $\mathrm{pH}\left(\operatorname{after} V_{\mathrm{e}_{2}}\right)$ [36]. The total concentration of the reacting protons at each back-titration point was then calculated using the Eq. (3). The data points from the hydroxide titration, commencing after the ZPT calibration, were utilized in a nonlinear least-squares optimization program (FITEQL 4.0) to estimate the surface site concentrations and surface acidity constants.

Fig. 7 gives the plot of the acid-base titration curves of the lignin under different ionic strengths. When the $\mathrm{pH}$ was lower than 4.2 no significant differences were observed among the curves because at this stage the hydroxide ions added during titration reacted with the excess $\mathrm{H}^{+}$in the suspension. However, some differences among the curves of the ionic strengths were observed at higher $\mathrm{pH}$ because the hydroxide ions added reacted with the surface functional groups on the lignin surfaces and the reaction was affected by the ionic strength. In order to 

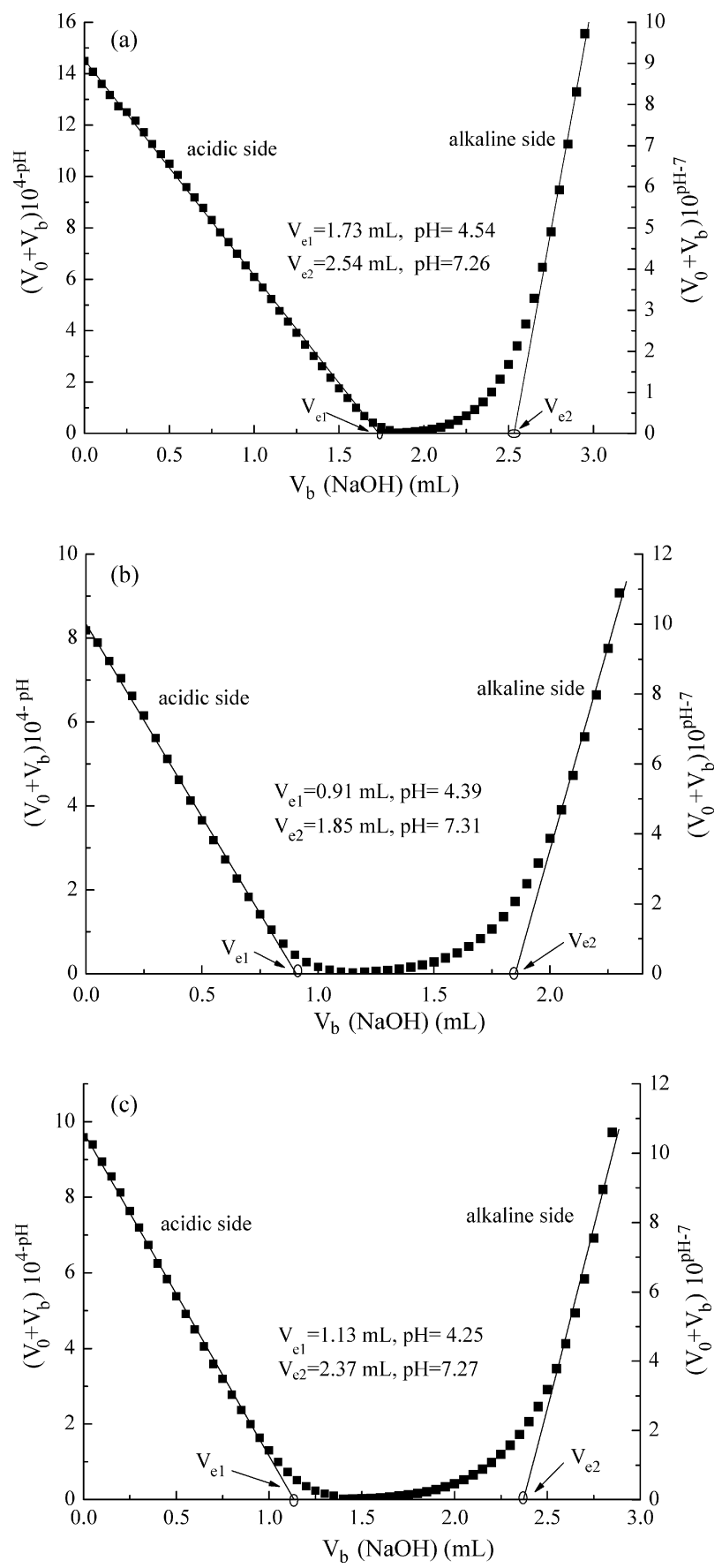

Fig. 6. Gran plots of the lignin sample at different ionic strengths: (a) $0.005 \mathrm{M}$, (b) $0.01 \mathrm{M}$, and (c) $0.1 \mathrm{M}\left(\mathrm{NaNO}_{3}\right)$.

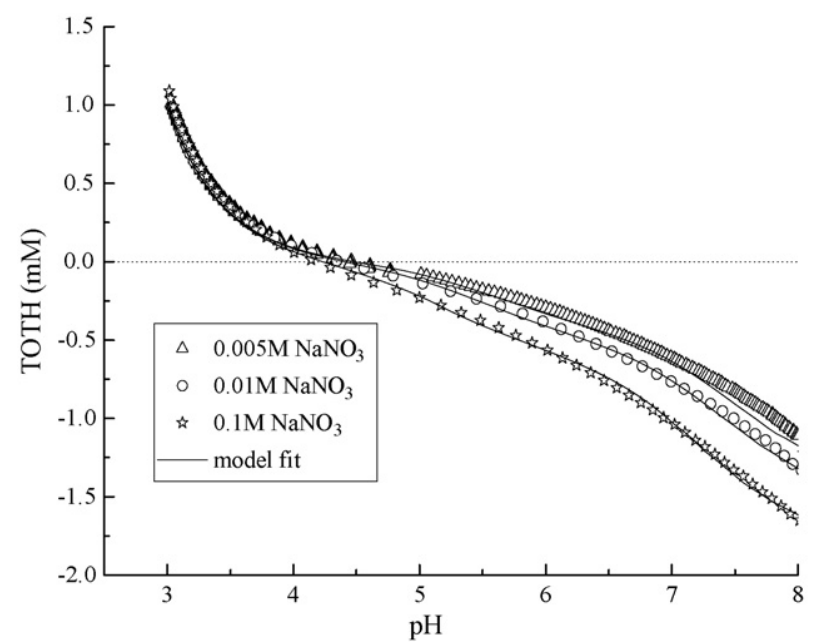

Fig. 7. Acid and base titration of the lignin at three ionic strengths. The solidto-solution ratio was $2 \mathrm{~g} / \mathrm{L}$. $\mathrm{NaNO}_{3}$ was used as the background electrolyte. The model fits are derived from the parameters in Table 3.

simplify the numbers of the adjusting parameters, the proton binding behavior of the lignin can be described using a nonelectrostatic surface complexation model. Lignin contains two major types of functional groups that have strong interactions with metal ions: carboxylic and phenolic groups [41-43]. These two types of sites have often been used to describe the metal ion binding to humic substances, which contain carboxylic and phenolic groups as the main surface functional groups [44-46]. Therefore a two-site model was used to fit the titration data. The acidity constants and site concentrations for the two types of surface functional groups are summarized in Table 3. Values of the WSOS/DF provided by the FITEQL 4.0 code are used as a measure for the quality of fit, and values between 0.1 and 20 indicate a reasonably good fit [35]. WSOS/DF values for the two-site model at three ionic strengths are 2.16, 1.23, and 1.60, respectively, indicating an excellent fit to the experimental data. The surface acidity constants were found to be $\log \mathrm{Ka}_{1}=-5.57$ to -5.20 and $\log \mathrm{Ka}_{2}=-7.51$ to -7.23 , respectively, attributed to the carboxylic- and phenolic-type surface groups. The results obtained are similar to those of Bouanda et al. [43], who reported the $\mathrm{p} K_{\mathrm{a}_{1}}$ and $\mathrm{p} K_{\mathrm{a}_{2}}$ values of 5.51 and 7.22, respectively, for a lignocellulosic substrate originating from wheat bran. The results also indicate that there are over twice as many proton active phenolic groups located on lignin compared to the carboxylic groups, which is consistent with the results obtained by FT-IR, in which we observed that lignin was rich in phenolic groups and contained fewer carboxylic groups.

Table 3

Concentration and acidity constants for surface functional groups of lignin at different ionic strengths

\begin{tabular}{|c|c|c|c|c|c|}
\hline \multirow[t]{2}{*}{ Ionic strength } & \multicolumn{2}{|l|}{$\mathrm{S}_{1} \mathrm{OH}$} & \multicolumn{2}{|l|}{$\mathrm{S}_{2} \mathrm{OH}$} & \multirow[t]{2}{*}{ WSOS/DF } \\
\hline & {$\left[\mathrm{S}_{1} \mathrm{OH}\right]^{\mathrm{a}}(\mathrm{mmol} / \mathrm{g})$} & $\log K_{\mathrm{a} 1}$ & {$\left[\mathrm{~S}_{2} \mathrm{OH}\right]^{\mathrm{b}}(\mathrm{mmol} / \mathrm{g})$} & $\log K_{\mathrm{a} 2}$ & \\
\hline $0.005 \mathrm{M} \mathrm{NaNO}_{3}$ & 0.21 & -5.57 & 0.51 & -7.51 & 2.16 \\
\hline $0.01 \mathrm{M} \mathrm{NaNO}_{3}$ & 0.24 & -5.46 & 0.53 & -7.42 & 1.23 \\
\hline $0.10 \mathrm{M} \mathrm{NaNO}_{3}$ & 0.29 & -5.20 & 0.63 & -7.23 & 1.60 \\
\hline
\end{tabular}

${ }^{a} \mathrm{~S}_{1} \mathrm{OH}$ refers to carboxylic-type sites.

b $\mathrm{S}_{2} \mathrm{OH}$ refers to phenolic-type sites. 
Table 4

Surface complexation reactions and model parameters describing metal ion adsorption on lignin

\begin{tabular}{|c|c|c|c|c|c|}
\hline \multirow[t]{2}{*}{ Surface complexation equilibria } & \multicolumn{5}{|l|}{$\log K$} \\
\hline & $\mathrm{Pb}(\mathrm{II})$ & $\mathrm{Cu}(\mathrm{II})$ & $\mathrm{Cd}(\mathrm{II})$ & $\mathrm{Zn}(\mathrm{II})$ & $\mathrm{Ni}(\mathrm{II})$ \\
\hline $\mathrm{S}_{1} \mathrm{OH}+\mathrm{M}^{2+} \rightleftharpoons \mathrm{S}_{1} \mathrm{O} \mathrm{M}^{+}+\mathrm{H}^{+}$ & -0.46 & -0.52 & -1.25 & -1.35 & -1.33 \\
\hline $\mathrm{S}_{2} \mathrm{OH}+\mathrm{M}^{2+} \rightleftharpoons \mathrm{S}_{2} \mathrm{O} \mathrm{M}^{+}+\mathrm{H}^{+}$ & & & & -2.36 & \\
\hline $\mathrm{S}_{1} \mathrm{OH}+\mathrm{S}_{2} \mathrm{OH}+\mathrm{M}^{2+} \rightleftharpoons\left(\mathrm{S}_{1} \mathrm{O}\right)\left(\mathrm{S}_{2} \mathrm{O}\right) \mathrm{M}+\mathrm{H}^{+}$ & -1.24 & -1.84 & -3.38 & & -5.32 \\
\hline WSOS/DF & 5.3 & 1.51 & 0.44 & 3.85 & 10.60 \\
\hline
\end{tabular}

\subsection{Metal adsorption modeling}

The acidity constants and the site concentrations previously determined in $0.01 \mathrm{M} \mathrm{NaNO}_{3}$ were used to model the data for the metal adsorption on lignin as a function of $\mathrm{pH}$ (Fig. 4). The simple complexation model was applied to the experimental data for the adsorption of $\mathrm{Pb}(\mathrm{II}), \mathrm{Cu}$ (II), $\mathrm{Cd}(\mathrm{II}), \mathrm{Zn}$ (II), and $\mathrm{Ni}$ (II) on lignin. Both soluble hydroxo species $\mathrm{MOH}$ and $\mathrm{M}(\mathrm{OH})_{2}$ were taken into account in the calculation with the corresponding formation constants obtained from Dzombak and Morel [47].

For each metal we investigated the model using the formation of a 1:1 and 1:2 complex for each type of site (carboxylic and phenolic groups) to describe the data according to the following equations

$\mathrm{S}_{i} \mathrm{OH}+\mathrm{M}^{2+}=\mathrm{S}_{i} \mathrm{O}-\mathrm{M}^{+}+\mathrm{H}^{+}$

$2 \mathrm{~S}_{i} \mathrm{OH}+\mathrm{M}^{2+}=\left(\mathrm{S}_{i} \mathrm{O}\right)_{2} \mathrm{M}+2 \mathrm{H}^{+}$

$\mathrm{S}_{1} \mathrm{OH}+\mathrm{S}_{2} \mathrm{OH}+\mathrm{M}^{2+}=\left(\mathrm{S}_{1} \mathrm{O}\right)\left(\mathrm{S}_{2} \mathrm{O}\right) \mathrm{M}+2 \mathrm{H}^{+}$

$\mathrm{S}_{i} \mathrm{OH}+\mathrm{M}^{2+}+\mathrm{H}_{2} \mathrm{O}=\mathrm{S}_{i} \mathrm{OMOH}+2 \mathrm{H}^{+}$

Satisfactory agreement between the fitted and experimental curves was obtained only for $\mathrm{Pb}$ (II), $\mathrm{Cu}(\mathrm{II}), \mathrm{Cd}(\mathrm{II})$, and $\mathrm{Ni}$ (II) when the two complexes, $\mathrm{S}_{1} \mathrm{OM}^{+}$and $\left(\mathrm{S}_{1} \mathrm{O}\right)\left(\mathrm{S}_{2} \mathrm{O}\right) \mathrm{M}$, were introduced. For $\mathrm{Zn}(\mathrm{II})$, however, $\mathrm{S}_{1} \mathrm{OM}^{+}$and $\mathrm{S}_{2} \mathrm{OM}^{+}$had to be taken into account to obtain a satisfactory fit. Attempts were made to model the experimental data after the formation of $\left(\mathrm{S}_{2} \mathrm{O}\right)_{2} \mathrm{M},\left(\mathrm{S}_{1} \mathrm{O}\right)_{2} \mathrm{M}, \mathrm{S}_{1} \mathrm{OMOH}$ or $\mathrm{S}_{2} \mathrm{OMOH}$ was considered, but no convergence was obtained. The model fits obtained for $\mathrm{Pb}(\mathrm{II}), \mathrm{Cu}(\mathrm{II}), \mathrm{Cd}(\mathrm{II}), \mathrm{Zn}(\mathrm{II})$ and $\mathrm{Ni}$ (II) adsorption data on lignin are presented as solid lines in Fig. 4. The corresponding surface complexation constants fitted by the FITEQL 4.0 Program as well as the goodness-of-fit WSOS/DF are listed in Table 4. Good agreement between the calculated and the experimental curves for all the metals suggests that the surface complexation model reproduces the adsorption data reasonably well in the experimental conditions.

Judging from $\log K$ values obtained by the model fits, the phenolic sites appear to have a higher affinity for metal ions than the carboxylic sites, with the binding strength in the following sequence: for the carboxylic-type sites $\mathrm{Pb}$ (II) $>\mathrm{Cu}$ (II) $>\mathrm{Zn}$ (II), $\mathrm{Cd}(\mathrm{II}), \mathrm{Ni}(\mathrm{II})$; for the phenolic-type sites: $\mathrm{Pb}(\mathrm{II})>\mathrm{Cu}(\mathrm{II})>$ $\mathrm{Cd}(\mathrm{II})>\mathrm{Zn}(\mathrm{II})>\mathrm{Ni}(\mathrm{II})$. The sequence obtained is similar to the one obtained by Ravat et al. for these five metal ions binding to lignocellulosic substrate [41,42].

To illustrate the utility of this approach, the speciation of the metals exposed to lignin was calculated using the surface complexation reactions and the model parameters in Tables 3 and 4. The calculated speciation curves for $\mathrm{Cu}$ (II) and $\mathrm{Zn}$ (II) as a function of $\mathrm{pH}$ are illustrated in Fig. 8. At low $\mathrm{pH}$ the metals existed as free ions predominantly in the aqueous state. When the $\mathrm{pH}$ increased, the concentration of the free metal ions decreased and the carboxylic-type sites contributed significantly to the binding behavior by forming monodentate complexes $\mathrm{S}_{1} \mathrm{OM}^{+}$. At higher $\mathrm{pH}$, metal adsorption onto phenolic-type sites began to occur. For $\mathrm{Cu}(\mathrm{II})$, adsorption on both the carboxylic-type and phenolic-type sites was involved as the coexistence of monodentate complexes $\mathrm{S}_{1} \mathrm{OM}^{+}$and bidentate complexes $\left(\mathrm{S}_{1} \mathrm{O}\right)\left(\mathrm{S}_{2} \mathrm{O}\right) \mathrm{M}$. Simultaneously with the constant increase in $\mathrm{pH}$, the concentration of the free metal ions in the aqueous phase decreased, monodentate complexes $\mathrm{S}_{1} \mathrm{OM}^{+}$began to convert to bidentate complexes $\left(\mathrm{S}_{1} \mathrm{O}\right)\left(\mathrm{S}_{2} \mathrm{O}\right) \mathrm{M}$, therefore $\mathrm{Cu}(\mathrm{II})$ predominantly existed as bidentate complexes $\left(\mathrm{S}_{1} \mathrm{O}\right)\left(\mathrm{S}_{2} \mathrm{O}\right) \mathrm{M}$. In contrast to
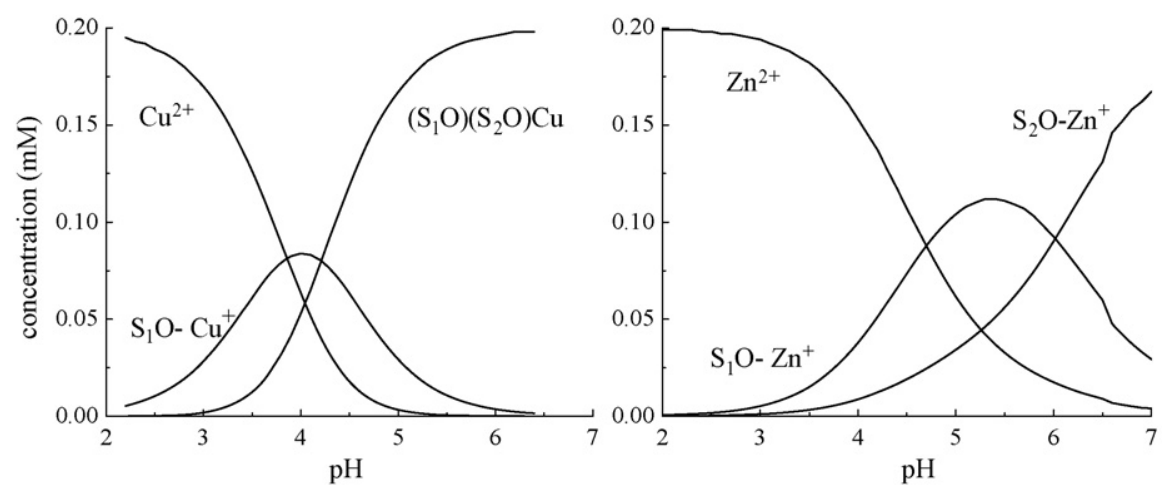

Fig. 8. Calculated speciation of metal ions $\mathrm{Cu}(\mathrm{II})$ and $\mathrm{Zn}(\mathrm{II})$ as a function of $\mathrm{pH}$ with $0.2 \mathrm{mM}$ metal ions exposed to $2.5 \mathrm{~g} / \mathrm{L}$ of lignin. 
$\mathrm{Cu}(\mathrm{II})$, only monodentate complexes $\mathrm{S}_{1} \mathrm{OM}^{+}$and $\mathrm{S}_{2} \mathrm{OM}^{+}$were observed for $\mathrm{Zn}$ (II). With increasing $\mathrm{pH}$ the concentration of the free metal ions in the aqueous phase also decreased, and the complexes $\mathrm{S}_{1} \mathrm{OM}^{+}$gradually converted to $\mathrm{S}_{2} \mathrm{OM}^{+}$. The curves for $\mathrm{Pb}(\mathrm{II}), \mathrm{Cd}(\mathrm{II})$, and $\mathrm{Ni}(\mathrm{II})$ were similar to $\mathrm{Cu}(\mathrm{II})$ and are therefore not shown here. This phenomenon may be explained by two factors. First, the phenolic sites had a higher affinity for metal ions than the carboxylic sites. Second, when the adsorption density increased the formation of $\mathrm{S}_{1} \mathrm{OM}^{+}$complexes led to the accumulation of positive charges on the lignin surface, thereby favoring the formation of the noncharged bidentate complexes $\left(\mathrm{S}_{1} \mathrm{O}\right)\left(\mathrm{S}_{2} \mathrm{O}\right) \mathrm{M}$. Metal ion adsorption onto deprotonated carboxyl and phenolic sites was the dominating mechanism that could reasonably explain the $\mathrm{pH}$ dependence adsorption behavior observed.

\section{Conclusions}

High adsorption capacities indicated that lignins have potential as adsorbents for removal of metals from water. For future application cost is another important factor we need to consider. Potentiometric titrations and model calculations show that lignin surfaces contain two main types of acid sites, attributed to carboxylic- and phenolic-type surface groups; the phenolic sites have a higher affinity for metal ions than the carboxylic sites. Metal ion adsorption onto deprotonated carboxyl and phenolic sites was the dominant mechanism that could reasonably explain the observed adsorption behavior. The results of the present study give us a quantitative description and fundamental understanding of the adsorption of metals on lignin. However, this study is based on a simple component with single metal ion. More complicated constituents exist in water and especially in wastewater. Competition among ions and potential transition of metal complexing ligands should be included in future studies in order to simulate waters in the environment.

\section{Acknowledgements}

This work was funded by the National natural science foundation of China (Grant No. 20621703) and Chinese academy of sciences (Grant No. KZCX3-SW-431).

\section{References}

[1] C. Gabaldon, P. Marzal, J. Ferrer, A. Seco, Single and competitive adsorption of $\mathrm{Cd}$ and $\mathrm{Zn}$ onto granular activated carbon, Water Res. 30 (1996) 3050-3060.

[2] K. Kadirvelu, C. Faur-Brasquet, P. Le Cloirec, Removal of $\mathrm{Cu}(\mathrm{II}), \mathrm{Pb}(\mathrm{II})$ and $\mathrm{Ni}(\mathrm{II})$ by adsorption onto activated carbon cloths, Langmuir 16 (2000) 8404-8409.

[3] D. Mohan, C.U. Pittman Jr., Activated carbons and low cost adsorbents for remediation of tri- and hexavalent chromium from water, J. Hazard. Mater B 137 (2006) 762-811.

[4] D. Mohan, K.P. Singh, V.K. Singh, Trivalent chromium removal from wastewater using low cost activated carbon derived from agricultural waste material and activated carbon fabric cloth, J. Hazard. Mater. 135 (2006) 280-295.
[5] D. Mohan, K.P. Singh, Single-multi-component adsorption of cadmium and zinc using activated carbon derived from bagasse - an agricultural waste, Water Res. 36 (2002) 2304-2318.

[6] B.W. Atkinson, F. Bux, H.C. Kasan, Considerations for application of biosorption technology to remediate metal-contaminated industrial effluents, Water SA 24 (1998) 129-135.

[7] S.M. Lee, A.P. Davis, Removal of Cu (II) and Cd (II) from aqueous solution by seafood processing waste sludge, Water Res. 35 (2001) 534-540.

[8] C.C. Liu, M.K. Wang, Removal of nickel from aqueous solution using wine processing waste sludge, Ind. Eng. Chem. Res. 44 (2005) 1438-1445.

[9] V.K. Gupta, D. Mohan, S. Sharma, K.T. Park, Removal of chromium(VI) from electroplating industry wastewater using bagasse fly ash - a sugar industry waste, Environmentalist 19 (1999) 129-136.

[10] J.M. Wang, X.J. Teng, H. Wang, H. Ban, Characterizing the metal adsorption capability of a class F coal fly ash, Environ. Sci. Technol. 38 (2004) 6710-6715.

[11] D. Mohan, S. Chander, Single, binary, and multicomponent sorption of iron and manganese on lignite, J. Colloid Interface Sci. 299 (2006) 76-87.

[12] D. Mohan, S. Chander, Removal and recovery of metal ions from acid mine drainage using lignite - A low cost sorbent, J. Hazard. Mater. 137 (2006) $1545-1553$.

[13] S. Al-Asheh, Z. Duvnjak, Sorption of cadmium and other heavy metals by pine bark, J. Hazard. Mater. 56 (1997) 35-51.

[14] G. McKay, J.F. Porter, Equilibrium parameters for the sorption of copper, cadmium and zinc ions on peat, J. Chem. Technol. Biotechnol. 69 (1997) 309-320.

[15] X.H. Chen, T. Gosset, D.R. Thevenot, Batch copper ion binding and exchange properties of peat, Water Res. 24 (1990) 1463-1471.

[16] S.K. Srivastava, A.K. Singh, A. Sharma, Studies on the uptake of lead and zinc by lignin obtained from black liquor- a paper industry waste material, Environ. Technol. 15 (1994) 353-360.

[17] S.B. Lalvani, T.S. Wiltowski, D. Murphy, L.S. Lalvani, Metal removal from process water by lignin, Environ. Technol. 18 (1997) 1163-1168.

[18] S.B. Lalvani, A. Hubner, T.S. Wiltowski, Chromium adsorption by lignin, Energy Source. 22 (2000) 45-46.

[19] J. Wieber, F. Kulik, B.A. Pethica, P. Zuman, Sorptions on lignin, wood and celluloses. III. Copper(II) and zinc(II) ions, Colloids Surf. 33 (1988) $141-152$.

[20] D. Mohan, C.U. Pittman Jr., P.H. Steele, Single, binary and multicomponent adsorption of copper and cadmium from aqueous solutions on kraft lignin - a biosorbent, J. Colloid Interface Sci. 297 (2006) 489504

[21] D.R. Crist, R.H. Crist, J.R. Martin, A new process for toxic metal uptake by a kraft lignin, J. Chem. Technol. Biotechnol. 78 (2003) 199_ 202

[22] R.H. Crist, J.R. Martin, D.R. Crist, Heavy metal uptake by lignin: comparison of biotic ligand models with an ion-exchange process, Environ. Sci. Technol. 36 (2002) 1485-1490.

[23] R.H. Crist, J.R. Martin, D.R. Crist, Use of a novel formulation of kraft lignin for toxic metal removal from process waters, Sep. Sci. Technol. 39 (2004) 1535-1545.

[24] A. Demirbas, Adsorption of lead and cadmium ions in aqueous solutions onto modified lignin from alkali glycerol delignication, J. Hazard. Mater. B 109 (2004) 221-226.

[25] A. Celik, A. Demirbas, Removal of heavy metal ions from aqueous solutions via adsorption onto modified lignin from pulping wastes, Energy Source. 27 (2005) 1167-1177.

[26] S. Babel, T.A. Kurniawan, Low-cost adsorbents for heavy metals uptake from contaminated water, J. Hazard. Mater. B 97 (2003) 219-243.

[27] S.E. Bailey, J.O. Trudy, R.M. Bricka, D.D. Adrian, A review of potentially low-cost sorbents for heavy metals, Water Res. 33 (1999) 2469-2479.

[28] R.J.A. Gosselink, E. deJong, B. Guran, A. Abächerli, Coordination network for lignin - standardization, production and applications adapted to market requirements (Eurolignin), Ind. Crop. Prod. 20 (2004) 121-129.

[29] D. Mohan, C.U. Pittman Jr., P.H. Steele, Pyrolysis of wood/biomass for bio-oil: a critical review, Energy Fuels 20 (2006) 848-889.

[30] K.V. Sarkanen, C.H. Ludwig, Lignins: Occurrence, Formation, Structure and Reactions, Wiley-Interscience, New York, 1971. 
[31] Suhas, P.J.M. Carrott, M.M.L. Ribeiro Carrott, Lignin - from natural adsorbent to activated carbon: a review, Bioresour. Technol. 98 (2007) 2301-2312.

[32] J.D. Rhodes, Cation exchange capacity, in: A.L. Page, R.H. Miller, D.R. Keeney (Eds.), Methods of Soil Analysis. Part 2: Chemical and Microbiological Properties, American Society of Agronomy, Madison, WI, 1982, pp. $149-158$.

[33] Y.S. Ho, G. McKay, A comparison of chemisorption kinetic models applied to pollutant removal on various sorbents, Trans. Inst. Chem. 76B (1998) 332-340.

[34] Y.S. Ho, G. McKay, The kinetics of sorption of divalent metal ions onto sphagnum moss peat, Water Res. 34 (2000) 735-742.

[35] A. Herbelin, J. Westall, FITEQL: A Computer Program for Determination of Chemical Equilibrium Constants from Experimental Data. Version 4. 0, Department of Chemistry, Oregon State University, Corvallis, OR, 1999.

[36] Z.S. Chu, W.X. Liu, H.X. Tang, T.W. Qian, S.S. Li, Z.T. Li, G.B. Wu, Surface acid-base behaviors of Chinese Loes, J. Colloid Interface Sci. 252 (2002) 426-432.

[37] D.L. Sparks, Environmental Soil Chemistry, Academic, SanDiego, CA, USA, 2003.

[38] D. Ibarra, J.C. del Río, A. Gutiérrez, I.M. Rodríguez, J. Romero, M.J. Martínez, A.T. Martínez, Chemical characterization of residual lignins from eucalypt paper pulps, J. Anal. Appl. Pyrolysis 74 (2005) 116-122.

[39] A. Tejado, C. Pen, J. Labidi, J.M. Echeverria, I. Mondragon, Physicochemical characterization of lignins from different sources for use in phenol-formaldehyde resin synthesis, Bioresour. Technol. 98 (2007) 1655-1663.

[40] S.Y. Lin, C.W. Dence, General structure features of lignins, in: S.Y. Lin, C.W. Dence (Eds.), Methods in Lignin Chemistry, Springer, Berlin, 1992, pp. 1-17.

[41] C. Ravat, J. Dumonceau, F. Monteil-Rivera, Acid/base and Cu(II) binding properties of natural organic matter extracted from wheat bran: modeling by the surface complexation model, Water Res. 34 (2000) 1327-1339.

[42] C. Ravat, F. Monteil-Rivera, J. Dumonceau, Metal ions binding to natural organic matter extracted from wheat bran: application of the surface complexation model, J. Colloid Interface Sci. 225 (2000) 329-339.

[43] J. Bouanda, L. Dupont, J. Dumonceau, M. Aplincourt, Use of a Nica-Donnan approach for analysis of proton binding to a lignocellulosic substrate extracted from wheat bran, Anal. Bioanal. Chem. 373 (2002) 174-182.

[44] E. Tipping, M.A. Hurley, A unifying model of cation binding by humic substances, Geochim. Cosmochim. Acta 56 (1992) 3627-3641.

[45] M.F. Benedetti, C.J. Milne, D.G. Kinniburgh, W.H. van Riemsdijk, L.K. Koopal, Metal ion binding to humic substances: application of the non-ideal competitive adsorption model, Environ. Sci. Technol. 29 (1995) 446-457.

[46] D.G. Kinniburgh, C.J. Milne, M.F. Benedetti, J.P. Pinheiro, J. Filius, L.K. Koopal, W.H. van Riemsdijk, Metal ion binding by humic acid: application of the Nica-Donnan model, Environ. Sci. Technol. 30 (1996) 1687-1698.

[47] D.A. Dzombak, F.M.M. Morel, Surface Complexation Modeling: Hydrous Ferric Oxide, Wiley, New York, 1990. 